\title{
Information Asymmetry and Bank Credit Rationing for Small and Medium-Sized Enterprises in Congo
}

\author{
Ngakosso Antoine, Etokabeka Stanislas, Dih Arnold Gustave \\ Marien Ngouabi University, Brazzaville, Congo \\ Email: a.ngakosso@umng.cg, aimebeka@yahoo.fr, gustavedih@gmail.com
}

How to cite this paper: Antoine, N., Stanislas, E., \& Gustave, D. A. (2021). Information Asymmetry and Bank Credit Rationing for Small and Medium-Sized Enterprises in Congo. Open Journal of Social Sciences, 9, 42-52.

https://doi.org/10.4236/jss.2021.97004

Received: May 31, 2021

Accepted: July 11, 2021

Published: July 14, 2021

Copyright $\odot 2021$ by author(s) and Scientific Research Publishing Inc. This work is licensed under the Creative Commons Attribution International License (CC BY 4.0).

http://creativecommons.org/licenses/by/4.0/

\begin{abstract}
This work aims to analyze the factors that explain the bank credit rationing to small and medium sized enterprises in Congo. Based on the survey made by the BEA (2015) involving 289 small and medium sized enterprises (SMSE) related to the access to credit very small and medium sized enterprises (SMSE) in Congo, we achieve this objective by using the logistic regression. As results of estimations, baking credit rationing in Congo is influenced by six variables such as: submission of all information required by the banker to the client, the capacity to present mortgage guarantee, choice of credit line, formal accounting management, to be registered near the chamber of commerce, and have invested early 12 months.
\end{abstract}

\section{Keywords}

Baking Credit Rationing, Small and Medium Sized Enterprises

\section{Introduction}

Most studies show that small and medium-sized enterprises (SMEs) influence economic activities in both developed and developing countries (Rapport, 2015). They account for more than $95 \%$ of all enterprises and $60 \%-70 \%$ of employment. These are considered the locomotive of development and growth of any economy, and are an indispensable source of dynamism and flexibility (Tari \& Attari, 2018). Indeed, entrepreneurs can resort to either equity or external financing, particularly bank loans, to enable the smooth development of their businesses. Access to bank financing is an indispensable condition for the development of this sector.

Despite their importance in economies, SMEs face many obstacles, the most 
importance of which is bank financing. The restriction of bank credit does not allow SMEs to finance their activities and consequently to grow. While, in sub-Saharan Africa, SMEs constitute almost all of the enterprises, i.e. more than $90 \%$ in the DRC, nearly $99 \%$ in Cameroon and $80 \%$ in Congo Brazzaville (Nkouka et al., 2013). In Congo, the turnover of 300 SMEs represents nearly CFAF 3.5 billion, and for a number of jobs of nearly 2500 (Massika, 2017).

However, in the current context of the Congolese economy, which is struggling to recover and is characterized by dependence on oil, SMEs should be at the center of any financing policy in order to revive the economy, instead of dismissing them by rationing credit.

However, the SME sector presents several difficulties, as it is generally complex to determine the opacity of SMEs, since banks face a serious problem of information asymmetry (Berger \& Udell, 2006). To protect themselves against these risks, banks ask for collateral, require certain necessary information (accounting documents) or simply ration credit. Stiglitz and Weiss (1981) point out that this anti-selection situation and moral hazard can lead banks to ration credit. Raising the interest rate can scare away honest borrowers by leaving the riskiest borrowers in the credit market. Sometimes banks also have to comply with Basel II standards.

In view of this situation, our study analyzes, on the one hand, the informational asymmetry on the restriction of bank credit, and on the other hand, the impact of the guarantee on the rationing of bank credit.

Thus, this study seeks to answer the following questions:

Do SMEs provide the necessary information when applying for a bank loan?

Are banks rationing bank credit?

The objective of this work is to analyze, on the one hand, information asymmetry and credit rationing, and on the other hand, the presence of collateral and credit rationing.

To this end, in addition to the introduction and conclusion, this paper is structured around four points. The first presents the situation of bank financing of SMEs in Congo; the second reviews the literature; the third is devoted to the methodological analysis and the fourth deals with the conclusion and the economic policy implications.

\section{Situation of Banks in the Republic of Congo}

The Congolese banking system, which consisted of two banks in the second half of the 1990s, has grown to eleven (11) banks in 2014. However, reforms in financial liberalization have encouraged the entry and creation of several other banking institutions in Congo. Bank balance sheets showed an increase of 15.9\% in 2014 compared to $5.4 \%$ in 2013. Private sector deposits, held mostly on demand, grew by $16.0 \%$, while loans to the private sector, which account for $44.6 \%$ of the balance sheet total, grew by only 3.5\% in 2014 (Banque de France, 2014).

We note that Congolese banks are in a state of excess liquidity, but bank credit to SMEs remains deplorable (Table 1). 
Table 1. Changes in reserves of Congolese banks from 2010 to 2014 (In millions of CFA francs).

\begin{tabular}{ccccccc}
\hline Country & Reserves & $\begin{array}{c}\text { December } \\
2010\end{array}$ & $\begin{array}{c}\text { December } \\
2011\end{array}$ & $\begin{array}{c}\text { December } \\
2012\end{array}$ & $\begin{array}{c}\text { December } \\
2013\end{array}$ & $\begin{array}{c}\text { December } \\
2014\end{array}$ \\
\hline \multirow{2}{*}{ Congo } & Free reserves & 312.318 & 443.899 & 541.389 & 286.075 & 734.420 \\
& $\begin{array}{c}\text { Mandatory } \\
\text { reserves }\end{array}$ & 122.071 & 194.280 & 236.122 & 255.493 & 267.962 \\
& Gross reserves & 434.389 & 638.179 & 777.511 & 541.568 & 1002.382 \\
\hline
\end{tabular}

Sources: BEAC, 2015.

In 2014, in the BEAC accounts, the gross reserves of Congolese banks were 1002.3 billion CFA francs. The free reserves considered as excess liquidity not neutralized by the Central Bank, pointed to 7344.2 Million CFA Francs.

In light of the above, the issue of under-financing of SMEs by banks remains a concern. It is obvious that the reasons are not related to the weakness of liquidity in bank accounts, but rather to the real missions assigned to these banks and to the effect of the banking crisis of the 1980s.

\section{Review of the Literature}

This section is devoted to the confrontation of theoretical ideas and works dealing with the notion of bank credit rationing on SMEs.

Before the modern approach, the financial structure of the firm was modeled by Modigliani and Miller (1958). These authors were the first to formulate a model of corporate financing behavior. In a first approach, Modigliani and Miller (1958), state that the financial structure has no effect on the value of the firm. The positive effect of financial leverage is offset by a negative effect due to the increase in financial risk.

The gradual lifting of the assumptions of the neoclassical model (Modigliani \& Miller, 1958), namely the perfection of the market, the absence of asymmetric information, bankruptcy costs, transaction costs and interest costs on the mode of financing firms, has given rise to a new approach called the modern approach (the signal theory, the agency theory, the theory of asymmetric information, the theory of hierarchical financing, etc.).

Two theories of the modern approach are the subject of this study, namely:

Hierarchical funding theory;

The theory of asymmetric information and credit rationing.

\subsection{The Theory of Hierarchical Funding}

Theory modeled and introduced as a hierarchical financing theory by Myers and Majluf (1984). This theory puts forward the idea that companies give priority to internal financing over external financing. Here, we are talking about a hierarchy of types of financing. This theory recognizes the existence of information asymmetries that lead to inefficient investment decisions and reduce external financ- 
ing. In order to reduce these information asymmetries, firms must present guarantees or credible signals when choosing external financing.

As Bester (1994) points out, the use of guarantees is a classic solution to the problems of adverse selection and moral hazard. To the extent that shareholders have limited liability, the bank may approve credit to individual owners rather than to the firm. Collateral forces firms to do their best to repay the loan received. Similarly, Udell et al. (2008), in their research, acknowledge that collateral plays a large role in bank loan approval. SMEs have little collateral compared to large firms. They could provide more collateral than large firms for the same amount of loan by taking into account a low survival rate of the firm.

Empirically, Alexandre and Buisson (2010), conclude that the most rationed SMEs are younger and have no or less collateral. The estimation was carried out on a sample of 3957 French SMEs by applying the imbalance model. The existence of such rationing explains why the growth model of French SMEs seems to increasingly favor development within large firms.

Kasereka (2016), conducted a study in the city of Butembo on a population of 2428 SMEs using the statistical model, it emerges from his study that the reasons for credit rationing are the lack of collateral and bankable project.

Given the results obtained from the hierarchical theory on collateral and bank credit rationing, we support the hypothesis 1 that the submission of collateral by the SME reduces bank credit rationing.

However, Stiglitz and Weiss (1981), reject the collateral hypothesis put forth by Lopez and Maria (2008) and confirm that the requirement of higher collateral may push borrowers to undertake riskier projects to balance the opportunity cost caused by the firm's pledged collateral.

\subsection{Information Asymmetry and Liquidity Constraints}

Popularized by Akerlof (1970), this theory demonstrates that price is not necessarily synonymous with quality, which can be bad or good depending on how it evolves, due to asymmetric information. The introduction of imperfect information by certain theorists into neoclassical analysis calls into question the main results of competitive economics and makes the single equilibrium price on the market disappear.

Stiglitz and Weiss (1981) explained this issue (of credit rationing) by the asymmetry of information between the bank and the firm. They accept the idea that, in the presence of informational asymmetry, firms that are willing to pay a high interest rate are the riskiest. Some borrowers are priced out of the credit market regardless of the level of the interest rate because of the risk they present or because the bank has not been able to assess the risk properly. In addition, this informational asymmetry gives rise to moral hazard and anti-selection, and these do not allow the interest rate to balance the credit market.

Going in the same direction, Jappelli and Pagano (2005) believe that when informational exchanges are adequate, there can be four effects that are: 1) lower adverse selection, 2) lower borrower hold-up and bank information rents, 3) dis- 
ciplinary effect on borrowers, 4) elimination of incentives to over-indebtedness caused by dealing with multiple banks. When SMEs truly provide the necessary information that banks want, banks easily make loans.

On the empirical level, Joumady (1999) indicates that liberalization has been an important factor in reducing credit rationing for SMEs. He shows on the one hand that this liberalization has lifted exogenous requirements (rate caps, credit selectivity, etc.) and on the other hand, that it has reduced information asymmetry in the capital market. His empirical study focuses on Moroccan manufacturing firms belonging to the formal sector. His model was estimated on cross-sectional data by the ordinary least squares (OLS) method for the years 1988 to 1996, with 1989 being excluded due to missing data.

Nguena (2013), using a multinomial logit model, conducted a study on the main causes of credit rationing of 413 Cameroonian SMEs. The results are such that, Cameroonian SMEs are rationed because of the lack of accounting information. Most SMEs that are denied bank credit do not have accounting documents that can show the traceability of operations.

Based on the theory of informational asymmetry on credit rationing, we support the hypothesis 2 that asymmetric information positively influences credit rationing.

This review shows that information is not always perfect between banks and SMEs. This imperfection negatively affects the bank credit market and causes credit rationing. However, the presentation of the guarantee is a determining factor in the credit decision and can reduce this bank credit restriction. Thus, both hypotheses will be the subject of our study.

\section{Methodology}

This section is devoted to the methodological framework. In order to achieve the objective of this work, which is to analyze the factors that explain the credit rationing of SMEs in Congo, we draw on the work of Tuan-Anh (2009) on the credit rationing of SMEs in Vietnam. To do so, we use the logistic regression model. This method allows us to verify whether the independent variables can predict a dichotomous dependent variable, as it is also a modeling technique that, in its most widespread version, aims to predict and explain the values of a dependent variable (endogenous variable, variable to be predicted, explained variable, etc.) from the independent variables (predictor variables, explanatory variables, exogenous variables, etc.). The data used are collected from the BEAC (2015) survey on access to finance for MSMEs in the Republic of Congo on a sample of 289 SMEs.

\subsection{Presentation of Variables}

\subsubsection{The Dependent Variable}

\section{Credit application outcome variable (Ratios)}

SMEs acknowledged having applied for credit during the period covered by the questionnaire. The explained variable "bank credit rationing" is a binomial 
measure (application rejected; application totally or partially accepted) taking two modalities ( 0 and 1$)$.

$$
\text { Ratios }= \begin{cases}1 & \text { if the company has received the bank credit } \\ 0 & \text { if the company's request was rejected or partially received }\end{cases}
$$

\subsubsection{Independent Variables}

This section is devoted to the presentation of certain variables identified in the questionnaire. From a theoretical and empirical perspective, credit rationing is dependent on certain characteristics of the firm. Thus, for this study, the independent variables chosen are grouped in Table 2 .

\subsection{Formalized Specification of the Model}

Given the objective of this study, we have developed a simplified representation to understand, explain and, if necessary, predict the probability of SME rationing by banks in the Republic of Congo.

The functional form of the model to be tested is as follows:

$$
\begin{aligned}
\text { RATIOS }= & \beta_{0}+\beta_{1} \text { Age }+\beta_{2} \text { Emprunteurfournis }+\beta_{3} \text { Hypot }+\beta_{4} \text { Assur } \\
& +\beta_{5} \text { Lignecre }+\beta_{6} \text { Invest }+\beta_{7} \text { Se }+\beta_{8} \text { Fonctenquete }+\beta_{9} \text { Te } \\
& +\beta_{10} \text { Chif }+\beta_{11} \text { Compta }+\beta_{12} \text { Immat }+\beta_{13} \text { Employes }+\varepsilon
\end{aligned}
$$

where $\varepsilon$ is a random variable independent of the other variables. This variable $\varepsilon$ is the error or the deviation.

This specified cross-sectional model draws on the work of Cirhuza (2017),

\begin{tabular}{|c|c|c|}
\hline Authors & Theories & Questionnaire variables \\
\hline $\begin{array}{l}\text { Stiglitz and Weiss (1981); } \\
\text { Nguena (2013); } \\
\text { Oubdi and Amrhar (2013) }\end{array}$ & $\begin{array}{l}\text { Information asymmetry } \\
\text { and credit rationing }\end{array}$ & $\begin{array}{l}\text { The borrower provides all the } \\
\text { information requested by the } \\
\text { bank; Keeping formal accounts; } \\
\text { To be registered in the trade } \\
\text { register Sales figures }\end{array}$ \\
\hline Zambaldi et al. (2001) & & Age of the company \\
\hline (Lopez and Maria, 2008) & $\begin{array}{l}\text { Hierachical theory and } \\
\text { credit rationing (mortgage) }\end{array}$ & $\begin{array}{c}\text { Mortgage; } \\
\text { Outstanding balance insurance }\end{array}$ \\
\hline Berger et al. (2005) & Hierarchical funding theories & Have a line of credit; \\
\hline Psillaki (1995) & Financial theory of the firm & Investment in the last 12 months \\
\hline Nguena (2013) & $\begin{array}{l}\text { The hierarchical theory } \\
\text { and credit rationing }\end{array}$ & Number of companies \\
\hline Laurence (2002) & The theory of the signal & Respondent's function \\
\hline (Nguena, 2013) & Information asymmetry & Number of employees \\
\hline
\end{tabular}
who conducted a study on the determinants of bank credit rationing in BUKAVU City.

Table 2. Table of correspondence between variables and theories.

Source: Authors from the literature. 


\subsection{Model Estimation, Results and Interpretations}

\subsubsection{Estimation of the Model}

Estimating the model using the logit model gives us the following equation:

$$
\begin{aligned}
& \operatorname{Pr}(\text { RATIOS })=1.148288+(0.9340814) \text { Age }+(1.001188) \text { Age } 2 \\
& +1.310452(\text { Emprunteurfournis })+(0.5325285) \text { Hypot }+(1.653745) \text { Assur } \\
& +(0.5798512) \text { Lignecre }+(0.4491049) \text { Invest }+(1.106419) \text { Se } \\
& +(0.9082771) \text { Fonctenquete }+(1.253466) \mathrm{Te}+(0.8444498) \text { Chif } \\
& +(0.4522006) \text { Compta }+(5.807757) \text { Immat }+(1.243746) \text { Employes }
\end{aligned}
$$

\subsubsection{Statistical Tests}

Having evaluated the parameter vector $\beta$ and its variance-covariance matrix with a logit model, one can apply standard tests of constraints on the parameters. In particular, if one wants to test the significance of the model, i.e., the hypothesis: H0: $\beta 2=$ $\beta 3 \ldots=\beta \mathrm{k}=0$ in a model with $\mathrm{k}$ parameters, we can apply the likelihood ratio test.

$$
\mathrm{LR}=2
$$

where $\log \mathrm{L}$ is the value of the $\log \mathrm{L}$ function when the parameters are non-zero.

We can also use the coefficient of determination (pseudo $\mathrm{R}^{2}$ ) suggested by $\mathrm{Mc}$ Fadden $\mathrm{R}^{2} \mathrm{MF}$

$$
\mathrm{R}^{2} \mathrm{MF}=1
$$

\subsubsection{Presentation of Results and Interpretation}

Before interpreting the results, it is necessary to verify the quality and significance of the results.

The results of the model estimation indicate that $\mathrm{R}^{2}$ is relatively low (11.66\%).

The results from Table 3 indicate that there is a link between information asymmetry, collateral and credit rationing. The results obtained prove that six variables positively and significantly influence bank credit rationing.

- The variable the borrower provides all the requested information (loanprovided) is positively significant at the $10 \%$ threshold and negatively influences bank credit rationing, knowing that for the present work, SMEs providing the right information access credit more easily than SMEs that hide information. SMEs that provide the right information are 1.31 times more likely to access bank credit than those that withhold information. These results confirm the results of the empirical study by Nguena (2013), showing that SMEs without reliable information have less chance $(-2.53506)$ of benefiting from external financing, i.e. bank financing. In the Republic of Congo, it is shown that only $10 \%$ of SMEs are willing to provide the information requested by banks, and only these have access to bank credit.

- The mortgage variable (hypot) is significant at the $5 \%$ level, and has a sign consistent with the research hypothesis. In Congo, SMEs that present the mortgages requested by the bank as collateral have 0.532 times the chance of receiving a bank loan. This result confirms the results obtained by Alexander and Buisson (2010) showing that SMEs that present guarantees requested by banks have 0.101 more chance of receiving bank credit. 
Table 3. Marginal effects.

\begin{tabular}{ccc}
\hline Variables & $\mathrm{dy} / \mathrm{dx}$ & $p>\mathrm{IzI}$ \\
\hline Age & 0.9340814 & 0.147 \\
age $^{2}$ & 1.001188 & 0.402 \\
BorrowerProvided & $1.310452^{* * *}$ & 0.002 \\
Hypot & $0.5325285^{* *}$ & 0.043 \\
Assur & 1.653745 & 0.505 \\
Lignecred & $0.5798512^{\star}$ & 0.078 \\
Invest & $0.4491049^{* *}$ & 0.015 \\
Go to & 1.106419 & 0.740 \\
Function & 0.9082771 & 0.246 \\
Te & 1.253466 & 0.397 \\
Chif & 0.8444498 & 0.497 \\
Accounting & $0.4522006^{*}$ & 0.092 \\
Immat & $5.807757^{* * *}$ & 0.005 \\
Employees & 1.243746 & 0.260 \\
Constant & 1.148288 & 0.949
\end{tabular}

Source: authors, from spss software. Number of obs $=289$; LR chi2 (14) $=44.42$; Hosmer-Lemeshow chi2 $(8)=7.65 ;$ Prob > chi2 $=0.0001 ;$ Pseudo $R^{2}=0.1166 ;$ Log likelihood $=-168.26301 .{ }^{* *}=$ significant at $1 \%$; ${ }^{*}=$ significant at $5 \% ;{ }^{*}=$ significant at $10 \%$.

- The variable line of credit (linecred) is significant at the $10 \%$ level and influences the decision to grant credit, as SMEs that apply for a line of credit (the overdraft) are 0.6 more likely to receive bank credit. These results confirm the results obtained by Peng (2000), as the choice of financing by line of credit or by spot contract on American firms gives a high probability to firms to obtain credit. Thus, in the Republic of Congo, SMEs that apply for a bank line of credit have a 0.6 times higher chance of obtaining a bank loan.

- The variable investment made during the last 12 months (invest) is positively significant at the $5 \%$ threshold and negatively influences the liquidity constraint. Thus, SMEs whose managers present the documents including the entries and exits (opening balance sheet and closing balance sheet) of the last 12 months have 0.4491 more chance of receiving bank credit. This result confirms the results obtained by Kenfack (2016), he shows based on his study that obtaining a bank loan is negatively influenced by the attachment of the manager to the confidentiality of information concerning the past data of the company. In the case of Congo, the probability of obtaining a bank loan depends on the presentation of opening and closing balance sheets during a 12-month period.

- The variable keeping formal accounts is significant at the $10 \%$ threshold and has a positive and statistical influence on the granting of bank credit. That said, Congolese SMEs that use formal accounting have a 0.45 times greater 
chance of receiving a bank loan. This result confirms the results obtained by Nguena (2013), showing that Cameroonian SMEs are rationed because of the lack of accounting information.

- Being registered with the Chamber of Commerce (immat) is significantly positive at the $1 \%$ threshold. Thus, Congolese SMEs that are registered with the chamber of commerce have a 5.80 chance that banks will grant them the requested credit. This result confirms the results obtained by Djankov et al. (2007), who examined the determinants of private credit, using the rights of lenders and the private and public credit registers of 129 countries.

The results obtained allow us to confirm the theoretical and empirical predictions on the roles of informational asymmetry and collateral on bank credit rationing, and to draw the following lessons: the significant variables perfectly explain and confirm our study. SMEs must therefore reduce their opacity vis-à-vis banking institutions, present collateral, and be formal, i.e., be registered in the trade register in order to benefit from bank credit. They must keep formal accounts because keeping business accounts gives the company a certain credibility with regard to financial backers, have a line of credit such as an overdraft by presenting a guarantee to cover themselves against a repayment default, have a profitable investment over the past 12 months, and provide previous data to enable the bank to measure the company's capacity to meet its obligations (the liquidity ratio).

\section{Conclusion and Policy Implications}

The objective of this study was to analyze the factors that explain the rationing of bank credit to SMEs in Congo. The choice of the determinants of the capital structure was based on the theory of hierarchical financing and the theory of asymmetric information. The empirical analysis was based on a sample of 289 Congolese SMEs. The results obtained from the logistic regression model show that six variables are significant and perfectly explain credit rationing, thus confirming our research hypotheses. The reduction of information asymmetries between banks and SMEs reduces credit risk and, in turn, hinders credit rationing.

Our study highlights two managerial implications: first, the reasons for rationing are mainly due to the transparency of information; second, to protect themselves from bank rationing, SMEs need to certify accounting documents in order to reduce or limit the risk of credit refusal.

\section{Conflicts of Interest}

The authors declare no conflicts of interest regarding the publication of this paper.

\section{References}

Akerlof, G. (1970). The Market for Lemons: Quality Uncertainty and the Market Mechanism. Quarterly Journal of Economics, 84, 488-500. 
https://doi.org/10.2307/1879431

Alexandre, H., \& Buisson, H. (2010). L'impact de la crise sur le rationnement du crédit des PME françaises. Cahier de recherche de DRM.

Banque de France (2014). Numéro spécial Petites et Moyennes Entreprises. Bulletin mensuel de la Banque de France, 165, 31-48.

Banque des Etats de l'Afrique Centrale (BEAC), Conseil National du Crédit (CNC) (2015). Enquête sur l'accès au financement des TPME, en République du Congo. Plateforme des donnéesbasededonnées.

Berger, A. N., Miller, N. H., Petersen, A. M., Rajan, G. R., \& Stein, C. J. (2005). Does Function Follow Organizational Form? Evidence from the Lending Practices of Large and Small Banks. Journal of Financial Economics, 76, 237-269. https://doi.org/10.1016/j.jfineco.2004.06.003

Berger, A., \& Udell, G. (2006). Relationship Lending and Lines of Credit in Small Firm Finance. Journal of Business, 68, 351-381. https://doi.org/10.1086/296668

Bester, H. (1994). The Role of Collateral in a Model of Debt Renegotiation. Journal of Money, Credit and Banking, 26, 72-86. https://doi.org/10.2307/2078035

Cirhuza, M. (2017). Déterminants du rationnement des crédits des PME par les IMF de la ville de Bukavu. International Journal of Innovation and Scientific Research, 29, 50-57. http://www.ijisr.issr-journals.org

Djankov, S., McLiesh, C., \& Shleifer, A. (2007). Private Credit in 129 Countries. Journal of Financial Economics, 84, 299-329. https://doi.org/10.1016/j.jfineco.2006.03.004

Jappelli, T., \& Pagano, M. (2005). Information Sharing, Lending and Defaults: Cross.

Joumady, O. (1999). Libéralisation financière, rationnement du crédit et investissement des entreprises marocaines. Revue Région et Développement, No. 9.

Kasereka, M. (2016). Problématique du financement des PME par les établissements bancaires en RDC: Cas de la ville de Butembo.

Kenfack, M. (2016). L'obtention du crédit bancaire par les PME au Cameroun. Afrique et développement, 41, 121-158.

Laurence, D. (2002). Analyse empirique des PME Wallonnes en croissance. Université de Liège Faculté d'économie, de Gestion et de Sciences Sociales Ecole d'administration des Affaires.

Lopez, G., \& Mira, S. (2008). Testing Trade-Off and Pecking Order Theories Financing SMEs. Small Business Economics, 31, 117-136.

https://doi.org/10.1007/s11187-007-9088-4

Massika, K. (2017). Conference des nations unies sur le commerce et le developpement. CNUCED Projet 1415. P: Renforcement des capacités dans les secteurs pétrolier et minier dans les économies des pays de la CEEAC Atelier de formation sur la gouvernance de la chaîne de valeur dans le secteur extractif: Brazzaville, République du Congo.

Modigliani, F., \& Miller, H. (1958). The Cost of Capital, Corporation Finance and the Theory of Investment. The American Economic Review, 48, 261-297.

Myers, S., \& Majluf, N. (1984). Corporate Investment and Investment Decisions When Firms Have Information That Investor Do Not Have. Journal of Financial Economics, 13, 187-221. https://doi.org/10.1016/0304-405X(84)90023-0

Nguena, C. (2013). Le Financement des PME au Cameroun dans un Contexte de Crise Financière. Centre d'Etudes et de Recherche en Economie et Gestion Université de Yaoundé II Yaoundé, Cameroun Rapport de Recherche du FR-CIEA Nº 52/2013. 
Nkouka, S., Akono, C., \& Ndiwulu, B. (2013). PME et Innovation: Une analyse comparative entre le Cameroun, le Congo et la RDC, IDRC/CRDI, Dakar.

Oubdi, L., \& Amrhar, A. (2013). Rationnement du crédit en situation d'asymétrie d'information dans les PME de la ville Agadir. Résultats d'une enquête. 6ème Conférence internationale sur l'Economie et Gestion Des Réseaux "Economics and Management of Networks" EMN.

Peng, C. (2000). Loan Commitments vs Spot Loans: An Analysis of Borrower Choice. PhD Dissertation, Lexington, KY: The Graduate School, University of Kentucky.

Psillaki, M. (1995). Credit Rationing and Small and Medium Sized Firms: A Tentative of Linkage. Revue Internationale PME, 8, 67-90. https://doi.org/10.7202/1008359ar

Rapport, I. V. (2015). Les petites et moyennes entreprises et la création d'emplois décents et productifs. Geneve: Bureau International du Travail.

Stiglitz, J., \& Weiss, A. (1981). Credit Rationing in Markets with Imperfect Information. American Economic Review, 71, 393-410.

Tari, M., \& Attari, A. (2018). Le processus du financement bancaire de l'exploitation des $P M E$ et la notion d'effet de levier financier. Ecole Supérieure de Commerce; Revue des Economies Financières, Bancaires et de management-Numéro 06.

https://doi.org/10.37136/1996-000-006-007

Tuan-Anh, P. (2009). Le rationnement du crédit des PME Le cas du Vietnam. Thèse de doctorat, Paris: Université MONTPELLIER I.

Udell, M., Dorey, N., \& Wynne, C. (2008). Wolves Outperform Dogs in Following Human Social Cues. Animal Behaviour, 76, 1767-1773.

https://doi.org/10.1016/j.anbehav.2008.07.028

Zambaldi, F., Aranha, F., Lopes, H., \& Politi, R. (2011). Credit Granting to Small Firms: A Brazilian Case. Journal of Business Research, 64, 309-315.

https://doi.org/10.1016/j.jbusres.2009.11.018 